\title{
Conservative therapy of extensive unicystic ameloblastoma: a case report
}

\author{
Chang Lim Hyun', Ji-Young Song²* \\ 'Department of Pathology, Jeju National University Hospital, Jeju National University College of Medicine and Graduate School \\ of Medicine, Jeju, Republic of Korea \\ ${ }^{2}$ Department of Oral and Maxillofacial Surgery, School of Medicine, Jeju National University, Jeju, Republic of Korea
}

Ameloblastoma is a benign neoplasm originating from odontogenic epithelium. It is the most common neoplasm in the jaws and is characterized by aggressive behavior and local invasion. Unicystic ameloblastoma (UA) has a unilocular feature in radiologic examination and a cystic feature histologically. Decompression and marsupialization are conservative method of treatment of large UA. The purpose of decompression and marsupialization are size reduction of the mass, which makes it easy to handle at total enucleation with protection of nerve damage and facial deformity. Here we report successful conservative treatment of extensive UA using decompression and marsupialization with a review of literatures. (J Dent Rehabil Appl Sci 2018;34(3):246-50)

Key words: unicystic ameloblastoma; decompression; marsupialization

\section{Introduction}

Ameloblastoma is a benign neoplasm originating from odontogenic epithelium. ${ }^{1}$ It is the most common neoplasm in the jaws and is characterized by aggressive behavior and local invasion. ${ }^{2}$ Intraosseous ameloblastomas are classified into solid, unicystic, and multicystic types. ${ }^{3}$ According to the World Health Organization, unicystic ameloblastoma (UA) is similar to a cyst. ${ }^{4} \mathrm{UA}$ has a more favorable prognosis compared to solid and multicystic type and its recurrence rate ranges from $3.6 \%$ to $30.5 \%$ depending on the treatment method. ${ }^{2,5}$ The highest recurrence rate $(30.6 \%)$ is observed after simple enucleation, whereas the lowest recurrence rate $(3.6 \%)$

\footnotetext{
*Correspondence to: Ji-Young Song

Professor, Department of Oral and Maxillofacial Surgery, Jeju National University Hospital, 15, Aran 13-gil, Jeju-si, Jeju Special Self-Governing Province, 63241, Republic of Korea

Tel: +82-64-717-1845, Fax: +82-64-717-1102, E-mail: 2460song@naver.com Received: July 13, 2016/Last Revision: September 12, 2016/Accepted: February 5, 2018
}

is observed after resection; a recurrence rate of $18 \%$ was reported when marsupialization was used before curettage. ${ }^{6,7}$

Decompression and marsupialization are conservative method of treatment of large cysts and UA. ${ }^{6-8}$ The purpose of decompression and marsupialization are size reduction of the mass, which makes it easy to handle at total enucleation. ${ }^{6-8}$ The success of decompression and marsupialization are influenced by various factors, such as age, surgeon's technique, amount of incisional biopsy tissue during marsupialization, and close radiological follow-up. ${ }^{2}$

Here we report successful conservative treatment of extensive UA using conservative therapy with a review of literature.

Copyright(C) 2018 The Korean Academy of Stomatognathic Function and Occlusion. (c) It is identical to Creative Commons Non-Commercial License. 


\section{Case report}

A 12-year-old female patient was referred to the Department of Oral and Maxillofacial Surgery office for evaluation of facial swelling and a radiolucentic lesion in the left mandibular area. The swelling started one month ago. She had no medical history. Extraoral examination showed swelling and redness in the left submandibular area. Intraoral examination showed dental caries of \#75 and no bleeding or discharging in the oral cavity.

Dental panoramic view showed completely impacted \#35 and a unicystic radiolucent lesion in the left mandible (Fig. 1). Bone expansion and rarefaction was shown in computed tomography (Fig. 2). Perforation of the buccal and lingual sides of the mandible was also detected (Fig. 2). The size of the mass was approximately $4.5 \mathrm{~cm} \times 2.6 \mathrm{~cm} \times 2.9 \mathrm{~cm}$ (length $\times$ width $\times$ height). In laboratory analysis, all parameters were within normal ranges.

Decompression and marsupialization with incisional biopsy were performed under local anesthesia. Resected abnormal tissues and adjacent normal tis-

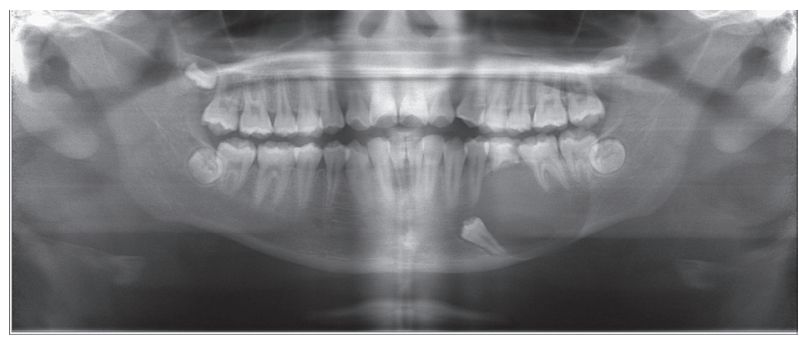

Fig. 1. Dental panoramic view. Large radiolucent lesion including \#35 is detected in the left mandible.
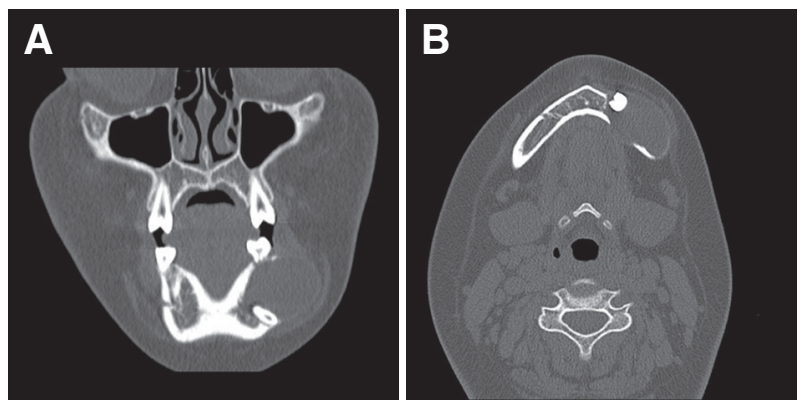

Fig. 2. Computed tomography (CT) view. Perforation of both side of the mandible is clearly detected. (A) Coronal view, (B) Axial view. sues from around the mass were subjected to histological analysis. A penrose drain tube was inserted into the mass to prevent gingival healing (Fig. 3). Histological diagnosis revealed UA. She had regular intraoral dressing. Six months after decompression and marsupialization, the size of the mass decreased to approximately $2.7 \mathrm{~cm} \times 0.8 \mathrm{~cm} \times 2.0 \mathrm{~cm}$. No perforation of the mandible was detected (Fig. 4). Eight months after decompression and marsupialization, the mass size further decreased to approximately 2.0 $\mathrm{cm} \times 0.8 \mathrm{~cm} \times 1.5 \mathrm{~cm}$ (Fig. 5). New bone formation

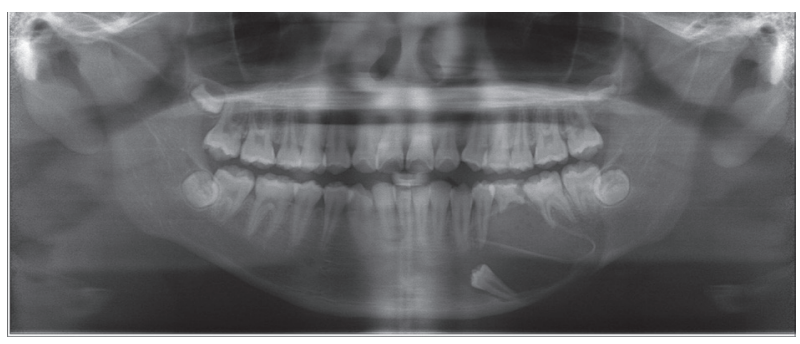

Fig. 3. Post operative dental panoramic view. A penrose drain is inserted into the mass.
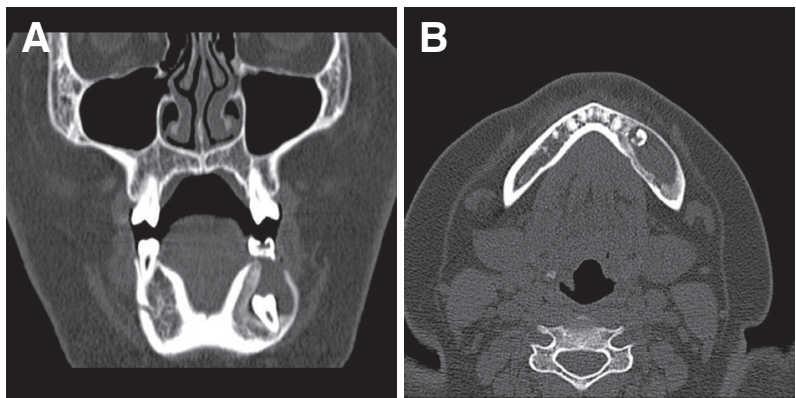

Fig. 4. CT view after 6 months follow-up. Perforation of mandible is not detected. (A) Coronal view, (B) Axial view.
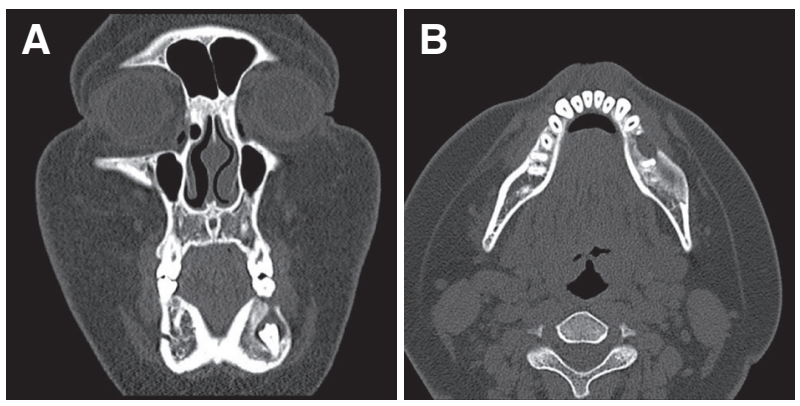

Fig. 5. CT view after 8 months follow-up. Marked newly formed bone is detected. (A) Coronal view, (B) Axial view. 
around the inferior alveolar nerve was detected (Fig. 6). Resection of the benign mass with surgical extraction of \#35 and \#75 was performed under general anesthesia. The resected mass was subjected to histological analysis and the final diagnosis was confirmed as UA (Fig. 7). After surgery, she had no hypoesthesia of the left chin and lower lip. After follow-up for 2 years, she had no recurrence of ameloblastoma and complete bone healing (Fig. 8). She is scheduled for orthodontic treatment.

\section{Discussion}

UA, which was first described by Robinson \& Martinez in 1977, has a unilocular feature in radiologic

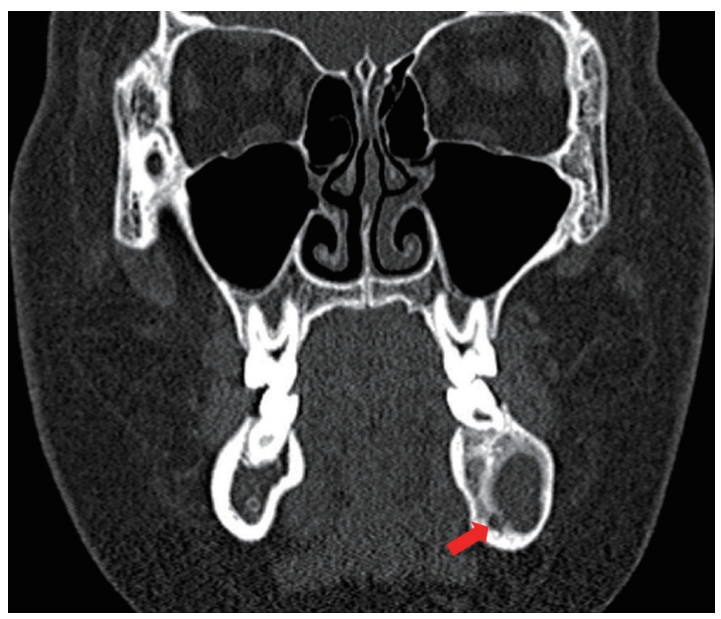

Fig. 6. The inferior alveolar nerve is protected with newly formed bone (arrow: inferior alveolar nerve). examination and a cystic feature histologically. ${ }^{1,3}$ The treatment options of UA are radical (resection and reconstruction using a reconstruction plate) or conservative (enucleation, enucleation after application of Carnoy's solution, or enucleation after marsupialization). ${ }^{1}$ The outcome of UA is better after conservative treatment compared to other types of ameloblastoma (solid and multicystic). ${ }^{7}$

In case of UA extending to the mandibular condyle or inferior alveolar nerve, radical resection might result in facial deformity and nerve damage, which directly influences quality of life. ${ }^{9-11}$

UA was classified into 3 subtypes by Ackermann histologically: subtype 1 is unilocular cystic luminal; subtype 2 is intraluminal with a solid growth inside lumen of the cystic lesion; and subtype 3 is intraluminal growth with mural invasion within adjacent tissues. ${ }^{2}$ Subtype 1 and 2 shows better treatment response to conservative treatments such as marsupial-

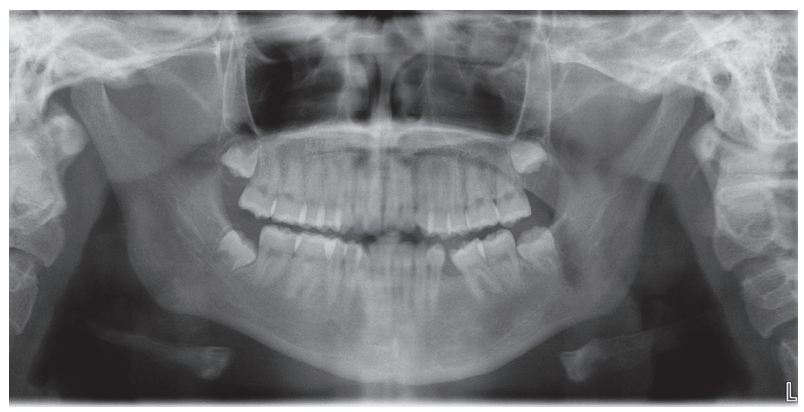

Fig. 8. Dental panoramic view after 2 years follow-up. Completely healed mandibular lesion is detected.
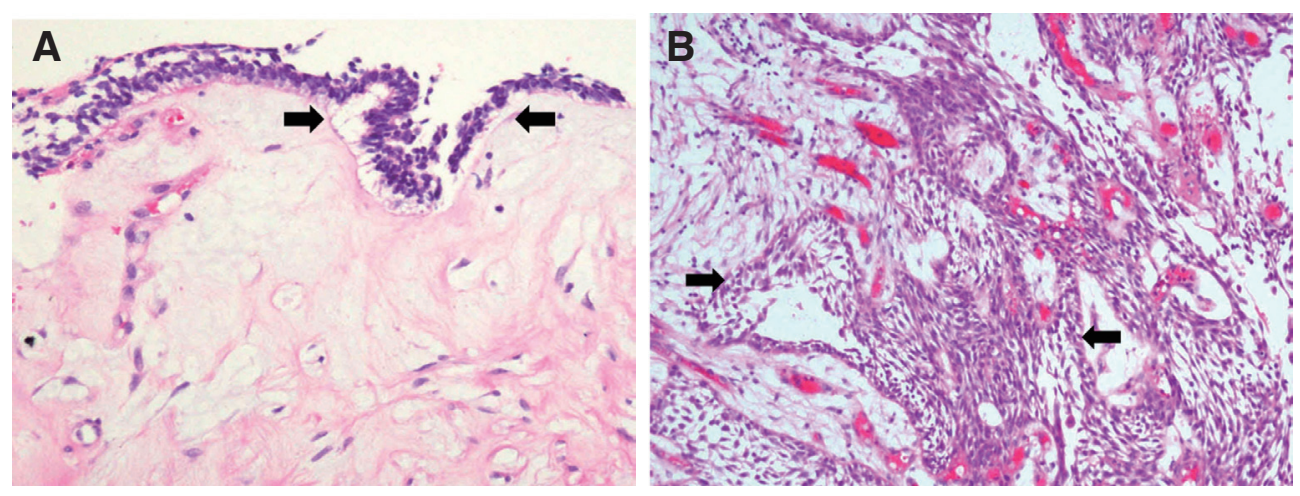

Fig. 7. Microscopically, unilocular cyst is lined by thin epithelium with ameloblastic changes such as basaloid appearance, palisading nuclei and subnuclear clearing (arrows). But it is confined to the cystic lining and shows a very thin lining ( $\times 200),(B)$ This unicystic tumor shows classic histologic features of ameloblastoma, palisading of the nuclei with reverse polarity and nuclear clearing is seen (arrows) $(\times 400)$. 
ization and enucleation. On the other hand, subtype 3 is treated with more aggressive treatment options such as resection. ${ }^{12}$ Therefore, it might be better that an incisional biopsy should be performed to determine the histopathologic subtype, for considering of treatment plan.

The rationale for conservative therapy is decompression of the mass using marsupialization. ${ }^{13}$ Mass decompression promotes bone remodeling and therefore osteogenesis. ${ }^{11,13}$ In our case, UA invaded the inferior alveolar nerve. Therefore, radical treatment would result in severe nerve damage. However, the use of decompression and marsupialization allowed to successfully performing nerve protection followed by osteogenesis around the inferior alveolar nerve 8 months after procedure. Hence, after surgery the patient had no nerve damage or facial deformity.

Because of the characteristics of UA, which is similar to a non-neoplastic odontogenic cyst, it can be misdiagnosed as an odontogenic keratocyst, dentigerous cyst, or other odontogenic cysts. Therefore, histological differential diagnosis is essential. ${ }^{9}$

In conclusion, because the resection of extensive UA might impair swallowing, mastication, and speech due to dentofacial deformity, especially in children, ${ }^{12}$ we recommend a conservative approach in children due to their development of the craniofacial region. Additional efforts for reducing recurrence rate will be needed.

\section{References}

1. de Paulo LF, Oliveira MT, Rodrigues ÁR, ZanettaBarbosa D. Treatment of an extensive unicystic ameloblastoma in a 7-year-old child: the best approach? Br J Oral Maxillofac Surg 2015;53:292-4.

2. Dolanmaz D, Etoz OA, Pampu A, Kalayci A, Gunhan O. Marsupialization of unicystic ameloblastoma: a conservative approach for aggressive odontogenic tumors. Indian J Dent Res 2011;22:709-12.

3. Robinson L, Martinez MG. Unicystic ameloblastoma: a prognostically distinct entity. Cancer 1977;40: 2278-85.

4. Sano K, Yoshimura H, Tobita T, Kimura S, Imamura Y. Spontaneous eruption of involved second molar in unicystic ameloblastoma of the mandible after marsupialization followed by enucleation: a case report. J Oral Maxillofac Surg 2013;71:66-71.

5. Souza Andrade ES, da Costa Miguel MC, Pinto LP, de Souza LB. Ameloblastoma and adenomatoid odontogenic tumor: the role of alpha2beta1, alpha3beta1, and alpha5beta1 integrins in local invasiveness and architectural characteristics. Ann Diagn Pathol 2007;11:199-205.

6. Sampson DE, Pogrel MA. Management of mandibular ameloblastoma: the clinical basis for a treatment algorithm. J Oral Maxillofac Surg 1999;57: 1074-7.

7. Lau SL, Samman N. Recurrence related to treatment modalities of unicystic ameloblastoma: a systematic review. Int J Oral Maxillofac Surg 2006;35: 681-90.

8. Pogrel MA. Decompression and marsupialization as a treatment for the odontogenic keratocyst. Oral Maxillofac Surg Clin North Am 2003;15:415-27.

9. Kessler HP. Intraosseous ameloblastoma. Oral Maxillofac Surg Clin North Am 2004;16:309-22.

10. Seintou A, Martinelli-Kläy CP, Lombardi T. Unicystic ameloblastoma in children: systematic review of clinicopathological features and treatment outcomes. Int J Oral Maxillofac Surg 2014;43:405-12.

11. De Melo WM, Pereira-Santos D, Sonoda CK, Pereira-Freitas SA, de Moura WL, de Paulo Cravinhos JC. Large unicystic ameloblastoma of the mandible: management guided by biological behavior. J Craniofac Surg 2012;23:e499-502.

12. Furuki Y, Fujita M, Mitsugi M, Tanimoto K, Yoshiga K, Wada T. A radiographic study of recurrent unicystic ameloblastoma following marsupialization. Report of three cases. Dentomaxillofac Radiol 1997;26:214-8.

13. Tomita Y, Kuroda S, Takahashi T, Ohura R, Tanaka E. Orthodontic occlusal reconstruction after conservative treatment of unicystic ameloblastoma in an adolescent patient: 10-year follow-up. Am J Orthod Dentofacial Orthop 2013;144:466-70. 


\section{낭종성 법랑아 세포종의 치험례: 증례 보고}

\section{현창림', 송지영 ${ }^{2 *}$}

${ }^{1}$ 제주대학교 의학전문대학원 병리학교실

${ }^{2}$ 제주대학교 의학전문대학원 치과학교실

법랑아 세포종은 치성 상피에서 기인한 양성 종양의 일종이다. 하악골에 가장 흔하게 발생하는 양성종양이며 공격적인 성장과 국소적 침범의 특징을 가진다. 그 중 단방성 법랑아 세포종은 방사선학적으로는 단방성의 특징을 가지며 병리학 적으로는 낭종의 특징을 가진다. 낭종성 법랑아 세포종의 병소의 크기가 큰 경우 감압술 및 조대술이 보존적인 치료 방 법으로 사용된다. 이 치료 방법의 목적은 병소의 크기를 줄여 완전 적출이 손쉽게 하며 악안면 부위 변형이나 신경 손상 을 방지하는데 있다. 본 증례에서는 병소의 크기가 큰 낭종성 법랑아 세포종을 감압술 및 조대술로 성공적으로 치료한 치험례를 논문 고찰과 함께 보고하고자 한다.

(구강회복응용과학지 2018;34(3):246-50)

주요어: 낭종성 법랑아 세포종; 감압술; 조대술 